\title{
EGFR Activating Mutation
}

National Cancer Institute

\section{Source}

National Cancer Institute. EGFR Activating Mutation. NCI Thesaurus. Code C92172.

A somatic mutation of the epidermal growth factor receptor gene which encodes a constitutively active $170 \mathrm{kDa}$ transmembrane protein, a short transmembrane region, and an intracellular domain. 